\title{
LABOUR AND ECONOMIC GROWTH THROUGH EDUCATION AND RESEARCH IN LATVIA
}

\author{
Santa Feifere, Peteris Zvidrins \\ University of Latvia
}

\section{Abstract}

The structure of Latvian economy and distribution of employees within it during last years has changed. Dealing with study of population, one can find young people share continuous decline and labour mean age increase, but in situation of economic slowdown Latvia also face challenge to develop knowledge-based economy. One of the means of helping to achieve the goal of becoming competitive and knowledge-based economy is through an investment in human capital. To ensure sustainable development there is a need to balance between social and economical growth using available resources. The theoretical concepts have shown that further growth has to be built on innovation, diffusion and adoption of new technologies and new products which increases competitiveness of the economy.

Attained educational level not only enhances the ability of a country to develop its own technological innovations, but also its ability to adapt and implement technologies developed elsewhere. Educated society can contribute from the transfer of latest technologies from abroad because any investment demonstrates stronger positive impact on economic growth in country with higher level of educational attainment. Attained education is relatively high in Latvia - 30.7\% of employed persons (15-74) and 15.4\% of job seekers (15-74) had attained higher education in 2010. If the labour market could not accommodate skilled workers it raises question of country's ability to use educational investments efficiently. According to the latest statistics (European Innovation Scoreboard 2010) Latvia has relative strength in human resources (new doctorate graduates, population completed tertiary education and youth with upper secondary level education), but Latvia is among 'modest innovators' taking last place in EU-27 range and its performance is estimated as well below that of the other countries of European Union (EU). The statistical data have showed that labour is more used in final good sector, not in research sector that produces technology in Latvia. Only $0.5 \%$ of labour in 2009 was employed in research and employment in knowledge-intensive service sectors was $26.8 \%$ of total employment in 2008. According to calculation the lowest added value to GDP per $1 \%$ of the labour was in agriculture and fishing caused by high proportion of labour allocated in this sector, but the highest added value to GDP was in financial mediation and business activities in 2009.

After accession in EU there are available structural funds for member states, also for implementation of practical research projects during EU structural funds 2007-2013 programming period in Latvia. These projects would promote integration of the science and manufacturing and were approved in 2010 and in the beginning of 2011. Implementing practical research projects scientific institutions are provided with opportunity to employ highly educated scientific personnel and develop innovative products and technologies influencing the changes in economic structure.

The research is based on statistical data analysis. Comparative and analytical methods have been mainly used in the paper taking into consideration the scientific literature.

Keywords: Ageing society, economic growth, labour, education, EU structural fund research projects.

\section{Introduction}

Latvian Strategic Development Plan 2010-2013 taking into account in Latvian National Development Plan 20072013 defined strategic aim and priorities, emphasis education and knowledge importance in economics development and technological excellence.

Identifying the impact of population ageing on labour supply in Latvia, the presumption is that an educated labour what is able to create, implement, and adopt new products and technologies could generate economic growth and establishment of knowledge-based economy in Latvia.

Noting the problem - ageing of total population and labour, it could be hard to ensure sustainable growth in Latvia because less labour is released to the labour market and fewer resources are accumulated for investment in economic development. This could become an obstacle for economic growth. Although the level of labour education is relatively high and according to European Innovation Scoreboard 2010 Latvia has relative strength in human resources (new doctorate graduates, population completed tertiary education and youth with upper secondary level education) Latvia is among 'modest innovators' taking last place in EU-27 range.

However, country which lies below the 'leader nation' in technology but possesses a higher human capital stock would catch up and overtake the leader in a finite time period (Benhabib, Spiegel 1994). Level of education not only enhances the ability of a country to develop its own technological innovations, but also its ability to adapt and implement technologies developed elsewhere since imitation tends to be cheaper than innovation.

The research novelty is related to fact that not many scientific papers analyse ageing society, labour and economic structure in Latvia.

The aim of the paper is to analyse theoretical concepts of ageing society accordance with labour and economic 
development through education and research in Latvia.

Research object is necessary preconditions for economic growth through education and science in Latvia.

To achieve the aim two tasks are to be solved:

1) to discuss the theoretic concepts of demographic change, education and research for economic growth;

2) to analyse the situation of quality of labour in Latvia.

The research methods are monographic descriptive, analysis and synthesis, statistical analysis and graphic illustration. Statistical analysis is built mainly on Central Statistical Bureau of Latvia and Eurostat data.

\section{Theoretical concepts of demographic change, education and research for economic growth}

There are authors who have been writing about demographic aspects in relation to economic development. Angeles (2010) stresses two closely related factors of economic development and technological progress related to demography - a richer and more technologically advanced economy may remunerate human capital better, and this would induce parents to increase their children's education at the expense of their number. Fertility decisions are linked with educational level of the children and educational level of their parents (Becker et al. 1990, Angeles 2010). It may make female labour relatively more effective, shifting women's choices towards more market employment and less child rearing (Galor, Weil 1996). Becker and Borro (1988) had developed model in which increased technological progress will lead to a higher rate of consumption and to lower rate of fertility.

In closed population, the population ageing can occur due to decline of fertility or mortality in mid and old ages. But these demographic processes have different socioeconomic subsequences and effects on economic development in the long run.

There are several authors who have been writing about depopulation and ageing society in Latvia (Krumins 1993, 2009, Zvidrins 2004, 2009, Depopulation in Latvia 2010, Eglite 2009). Studies of ageing society in Europe (Komp et al. 2009, Regions 2020 2009) and population projections by Eurostat and United Nations Population Division are also carried out.

Economists have devoted considerable attention to understand how human capital affects a variety of economic outcomes. Human capital would affect economic growth in two ways. First, human capital directly participates in production as a productive factor and the accumulation of capital directly generates output growth. Second, human capital can contribute in raising technical progress through increased innovation, diffusion and adoption of new technologies. From this indirect channel human capital influences growth through increases in productivity (Fougere 2009). Romer (1990) had suggested that the rate of technical change in country depends on its human capital endowments' identifying the differences between two types of human capital - used in final good sector and used in research sector that produces technology.

The presumption is that an educated labour is better at creating, implementing and adopting new technologies, thereby generating economic growth. Education speeds the process of technological diffusion and more educated will quicker introduce new processes and products (Nelson, Phelps 1966, Teixera, Fortuna 2010). A number of economic models of economic growth in fact emphasize the importance of scientists and engineers as key ingredient to growth. By these views, the technically trained college students who contribute to invention and to development of new products provide a special element to the growth equation (Hanuchek 2004). Science is a human activity enacted through distinctive social institutions, professional organizations, government (Global Governance of Science 2009). The level of science in different countries and regions of the world vary and are basically determinate by the levels of education and economic development (Silins 2004).

The knowledge is not separable from human capital and there are many definitions describing the meaning of it. In the Longman Dictionary of Contemporary English 'knowledge' is explained as the facts, skills, and understanding that one has gained through learning or experience. In fast changing and unpredictable environment the superior position is guaranteed only through the creation of new knowledge implemented in new products and services. Researchers are main element of research and development system and potential knowledge creators (Kersyte, Krisciunas, 2008). To ensure transition to knowledge-based economy some meaning emphasis has to be taken account (Figure 1).

\begin{tabular}{|c|c|c|}
\hline $1970-1980$ & $1980-1990$ & $1990-2000+$ \\
\hline Skills-based economy & Competence-based economy & Knowledge-based economy \\
\hline $\begin{array}{c}\text { OLD ECONOMY } \\
\text { preserving existing industries }\end{array}$ & $\begin{array}{l}\text { TRANSITION-TIME ECONOMY } \\
\text { adapting to industrial changes }\end{array}$ & $\begin{array}{c}\text { NEW ECONOMY } \\
\text { establishing knowledge-based industries }\end{array}$ \\
\hline $\begin{array}{l}\text { EMPHASIS on 'ability to do' skills. } \\
\text { Less attention } \\
\text { towards ‘ understanding'a ndpe rsonal } \\
\text { competencies (attitudes) }\end{array}$ & $\begin{array}{l}\text { EMPHSIS on } \\
\text { wide-scale comprehensive } \\
\text { competencies. Increasing more } \\
\text { attention to integrating } \\
\text { technological, social and personal } \\
\text { competencies and attitudes }\end{array}$ & $\begin{array}{l}\text { EMPHASIS on integrating formal and } \\
\text { informal (practice-based) knowledge and } \\
\text { know-how. } \\
\text { Including dimensions related to } \\
\text { business activities, technological, } \\
\text { sœ ial,ø ga ni zation la spe ctsa nd } \\
\text { self-management }\end{array}$ \\
\hline SKILLS, KNOWLEDGE, ATTITUDE & $\begin{array}{c}\text { SKILLS, KNOWLEDGE, } \\
\text { ATTITUDE }\end{array}$ & $\begin{array}{c}\text { SKILLS, KNOWLEDGE, } \\
\text { ATTITUDE }\end{array}$ \\
\hline SKILLED EMPLOYEE & COMPETENT EMPLOYEE & KNOWLEDGE-ABLE EMPLOYEE \\
\hline
\end{tabular}

Figure 1. Transition from skilled-based economy to knowledge-based economy

Source: author: Nyhan (2002), reference: Estonian Human Development Report 2007 
Countries cannot converge to the economically more advanced countries unless they have abundant levels of initial human capital stock and the more human capital level devoted to research, the higher growth of technology (Kyriacou 1991) what explains a shift in the demand towards educated labour.

Pointing out the education importance - education as indicator is included also in determination Knowledge Index (KI) and Knowledge Economy Index (KEI) which are introduced by The World Bank and European Innovation Scoreboard introduced by INNO METRICS.

One of the means of helping to achieve the goal of becoming competitive and knowledge-based economy is through an investment in human capital. Scientific and technological development has since been placed at the core of EU objectives, with an increasing interest in the role and measurement of skills within the labour (Europe in figures Eurostat yearbook 2010).

\section{Situation in Latvia}

Latvia is a small country with limited natural resources and 2.25 mil inhabitants at the beginning of 2010 which is 196.5 thousands inhabitants less than in the 1997 (number of children and young people under age 15 had decreased by 179.4 thousands, inhabitants aged 15-64 which mainly form labour had decreased by 62.4 thousands, only number of inhabitants older than 65 years had increased by 45.7 thousands). The share of young people has decreased from $20.0 \%$ to $14.0 \%$.

The number of inhabitants in Latvia decrease due to low birth rate, ageing population and emigration. The results of census organized by Central Statistical Bureau of Latvia which is held from March till May 2011 will introduce the actual amount of population in Latvia due to free movement of persons after accession in EU. Most likely the total number of population will be considerable lower than according official data of Central Statistical Bureau of Latvia.

Latvia is among most ageing countries in the world and has had a low fertility rate since the 1990s, which has not ensured even a simple level of population replacement that according to previously explanations would induce parents to increase their children's education. This causes consequences - less labour is released to the labour market and fewer resources are accumulated for investment in economic development. This could become an obstacle for economic growth in the future.

Retirement regulation is being discussed and used as a tool to decrease the number of retiring people and prolonging labour in labour market but it does not directly solve the problem of further growth of economics in country with high unemployment rate (18.7\% of labour aged 15-74 in 2010, Eurostat). Meanwhile the mean age of labour and economic active population increases.

Likewise, it is planned the retirement age to apply to those who insure the age of 62 years before $31^{\text {st }}$ December 2015 in Latvia. For younger, the retirement age will be increased gradually to 65 years starting from 2016. According to authors' calculation the mean age of economic active population (1564) and labour (15-64) has also increased - by 0.6 and 0.5 years during the period from 2002 till 2010. (Table 1).
Table 1. Mean age of labour and economic active population in Latvia, 2002-2010

\begin{tabular}{|c|c|c|c|c|}
\hline Year & $\begin{array}{l}\text { Labour (15- } \\
\text { 64) mean } \\
\text { age }\end{array}$ & $\begin{array}{l}\text { Base } \\
\text { increase } \\
\text { (years) }\end{array}$ & $\begin{array}{l}\text { Economic } \\
\text { active } \\
\text { popula-tion } \\
(15-64) \\
\text { mean age }\end{array}$ & $\begin{array}{l}\text { Base } \\
\text { increase } \\
\text { (years) }\end{array}$ \\
\hline 2002 & 40.1 & - & 39.7 & - \\
\hline 2003 & 40.0 & -0.1 & 39.8 & 0.1 \\
\hline 2004 & 40.3 & 0.2 & 40.0 & 0.3 \\
\hline 2005 & 40.3 & 0.2 & 40.1 & 0.4 \\
\hline 2006 & 40.2 & 0.1 & 40.0 & 0.3 \\
\hline 2007 & 40.2 & 0.1 & 40.0 & 0.3 \\
\hline 2008 & 40.4 & 0.3 & 40.2 & 0.5 \\
\hline 2009 & 40.9 & 0.8 & 40.3 & 0.6 \\
\hline 2010 & 40.7 & 0.6 & 40.2 & 0.5 \\
\hline
\end{tabular}

Source: authors' calculation based on Central Statistical Bureau data

Although the attained education is relatively high $-30.7 \%$ of employed persons (15-74) and 15.4\% (15-74) of job seekers had attained higher education in 2010, Latvia face economic slowdown what rises question of country's ability to use educational investments efficiently if the economy could not accommodate skilled workers. The attained education level by labour age differs. The employees in age group 25-39 has attained higher level of education - tertiary education - levels 5-6 (ISCED 1997) than employees in age group 50-64 that could ensure further economic development according to theoretical approaches discussed in advance (Figure 2.).

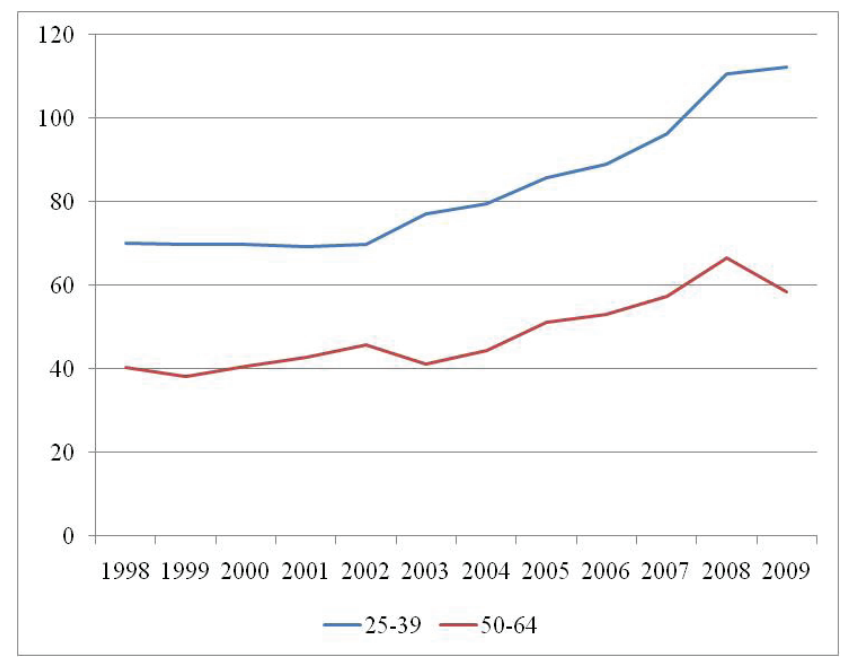

Figure 2. Employees by age groups (25-39 and 5064) and highest level of education attained - tertiary education - levels 5-6 (ISCED 1997) (1000)

Source: authors' calculation based on Eurostat data

According to Spence (1973) it could indicate that employers have used education and other observable human capital variables as a signal of unobservable worker ability. That could lead workers to invest in education even it provides no actual increase in productivity.

Innovative capacity is rooted in nation or region microeconomic environment and in field such as the intensity of scientists and engineers in the workforce. Analyzing labour 
as human capital devoted to research - total R\&D personnel by full time equivalent - the full time equivalent was 5485 in 2009 that is less than 1048 comparing with 2008 - the year with one of the highest result since 1993 (Central Statistical Bureau of Latvia). Only $0.54 \%$ of labour in 2007 and 2008, and $0.46 \%$ of labour in 2009 was employed in research (Eurostat), employment in knowledge-intensive service sectors was $26.8 \%$ of total employment in 2008 meanwhile in Norway the share of employment in knowledge-intensive service sectors was $46.7 \%$.

Authors identify that the level of scientific capacity of products and innovations can be described also by number of patents assuming that patents are one of the results of scientific activity. The number of patents registered in Latvia is low and not satisfactory - in 2008 there were 178 registered patents, in 2009 - 202, in 2010 - 184 (Patent Office of the Republic of Latvia).

The research results made by Melihovs and Davidsons (2006) emphasis that even if labour quality and technology could be identically to the average EU member states achieved, high proportion of industries that produce goods and services with relatively low added value in Latvia could become an obstacle to meet the maximum income level and technological innovation. Simultaneously it could be an alert for economic restructuring through labour concentration in economic sectors, but it raises more questions than it answers.
Authors did the analysis of the structure of economy on basis of employment and ratio of added value GDP. To ensure the comparison of the economic sectors authors integrated and nominated six economic sectors (according to NACE Rev.1.1.) - 1) agriculture and fishing $(\mathrm{A}+\mathrm{B}), 2$ ) industry, electricity, gas, and water supply (C-E), 3) construction (F), 4) retail trade, hotels, restaurants, transport, warehousing, communications (G-I), 5) financial mediation and business activities (J-K), 6) public administration and civil defence, compulsory social insurance, education, health care and social welfare etc. (L-Q).

The allocation of labour in economic sectors from 1997 till 2009 has changed. The share of agriculture and fishing $(A+B)$, industry, electricity, gas and water supply $(C-E)$ has declined, meanwhile importance of others has increased. In assessing the economic structure, authors did the comparison of ratio of the added value created to gross domestic product (GDP) and labour (L) in the given sectors. The most notable change in the economic structure in Latvia from 1997 to 2009 was the growth of such sectors as construction, financial mediation and business activities, and public administration and civil defence, compulsory social insurance, education, health care and social welfare etc. in the structure of added value. At the same time the share of agriculture and fishing, industry, electricity, gas, and water supply decreased. More detailed results are reflected in Table 2.

Table 2. Labour allocation and ratio of added value to GDP in Latvia, 1997 and 2009

\begin{tabular}{|c|c|c|c|c|c|c|c|c|c|c|c|c|}
\hline Sector & \multicolumn{2}{|c|}{$\mathrm{A}+\mathrm{B}$} & \multicolumn{2}{|c|}{ C-E } & \multicolumn{2}{|c|}{$\mathrm{F}$} & \multicolumn{2}{|c|}{ G-I } & \multicolumn{2}{|c|}{$\mathrm{J}-\mathrm{K}$} & \multicolumn{2}{|c|}{ L-Q } \\
\hline Year/ & $\mathrm{L}$ & GDP & $\mathrm{L}$ & GDP & $\mathrm{L}$ & GDP & $\mathrm{L}$ & GDP & $\mathrm{L}$ & GDP & $\mathrm{L}$ & GDP \\
\hline 1997 & 21.5 & 5.1 & 20.6 & 25.3 & 5.2 & 4.2 & 23.2 & 31.6 & 3.8 & 14.0 & 25.5 & 19.8 \\
\hline 2009 & 9.0 & 3.3 & 15.6 & 14.0 & 7.7 & 6.6 & 29.5 & 28.0 & 9.7 & 26.1 & 28.4 & 22.0 \\
\hline $\begin{array}{l}2009: \\
\text { GDP } \\
\text { value } \\
\text { added/ 1\% } \\
\text { labour }\end{array}$ & \multicolumn{2}{|c|}{0.367} & \multicolumn{2}{|c|}{0.897} & \multicolumn{2}{|c|}{0.857} & \multicolumn{2}{|c|}{0.949} & \multicolumn{2}{|c|}{2.691} & \multicolumn{2}{|c|}{0.775} \\
\hline $\begin{array}{l}\text { Rank } \\
\text { (des- } \\
\text { cending) }\end{array}$ & \multicolumn{2}{|c|}{6} & \multicolumn{2}{|c|}{3} & \multicolumn{2}{|c|}{4} & \multicolumn{2}{|c|}{2} & \multicolumn{2}{|c|}{ 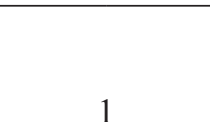 } & \multicolumn{2}{|c|}{ 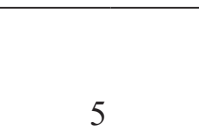 } \\
\hline
\end{tabular}

Source: authors' calculation based on Central Statistical Bureau data (note: according to statistical data L $(1997)=99.8 \%$, L (2009)= $99.9 \%)$

The results of calculation - added value to GDP per $1 \%$ of the labour in six sectors according to data in 2009 showed that the lowest added value to GDP per $1 \%$ of the labour was in agriculture and fishing caused by high proportion of labour allocated in this sector. The highest proportion was in financial mediation and business activities.

According to the latest statistics (European Innovation Scoreboard 2010) Latvia is among 'modest innovators' taking last place in EU-27 range. The performance of Latvia is estimated as well below that of the EU-27. Although the relative strengths are in such indicators as human resources (new doctorate graduates, population completed tertiary education and youth with upper secondary level education) and finance and support (public R\&D expenditure and venture capital), there are also relative weaknesses - open, excellent and attractive research systems (international scientific co-publications, scientific publications among top $10 \%$ most cited and non-EU doctorate students), linkages and entrepreneurship (SMEs Innovating in house, innovative SMEs collaboration with others, public-private co-publications) and innovators (SMEs introducing product or process innovations and marketing, organizational innovations). Latvia is not performing well in development of new products and innovations but at the same time there are different activities supported by EU. One of the opportunities to eliminate relative weaknesses is efficient use of available EU structural funds.

Since Latvia become a member of EU, the certain amount of EU funds has flown into the country. There is EU structural funds activity that is focused on financial support to practical research projects promoting integration of the science and manufacturing for universities and research institutes activity No. 2.1.1.1. 'Support to Science and Research' in the EU structural funds programming period 2007-2013. EU structural funds support provide the opportunity to employ highly educated scientific personnel for implementation of 
practical research projects and develop innovative products and technologies influencing the changes in economic structure.

The approved and contracted 123 projects (total expenditure 54.6 EUR mil, including European Regional Development Fund (ERDF) co-finance 48.3 mil EUR) are in accordance with the prior scientific directions of basic and applied research funding in Latvia till 2013. The expected results of implementation of these projects are increase of internationally recognised scientific publications and increase of number of patents.

15 of 123 projects are accepted in 2010 and in the beginning of 2011 (only $12.0 \%$ of total expenditure and $8.6 \%$ of ERDF co-finance) as projects in relation to economic activities which are implemented by private or state scientific institutions and/ or under the task of an entrepreneurs. Low interest to prepare projects in relation to economic activity could be explained by lack of opportunity to provide co-finance (for projects not in relation to economic activities co-finance rate is $7.5 \%$ of total eligible costs including maximum 5\% in-kind contribution as voluntary work, activities as professional nature, fixed assets and granted materials) and lack of collaboration with entrepreneurs (Mezeniece et.al. 2010).

According to regulation projects not related to economic activities are implemented by scientific institutions which perform the following primary activities - scientific activities and distribution of the results of scientific activities in the form of knowledge and technology transfer. All profits which have been acquired upon implementation of these primary activities are reinvested into the primary activities.

Although the proportion of projects not related to economic activities is large, implementation length of projects are for average $1 / 4$ longer than in projects not related to economic activities, there are positive aspects including sustained effect. The certain amount of finance will flow in higher education and scientific institutions compensating reduced funding from state budget and highly educated scientific personnel would be attracted to implementation of innovative products and technologies increasing their competences and competitiveness.

\section{Conclusions}

The demographic aspects in relation to economic development could be explained. Due to labour emigration and law fertility rate, less labour will be released to the labour market and fewer resources would be accumulated for investment in economic development in Latvia and one of the taken incentives is to increase retirement age.

$15.4 \%$ of job seekers had attained higher education in 2010 what shows that country could not use educational investments efficiently. The employees in age group 25-39 have attained higher level of education - tertiary education - than employees in age-group 50-64 that could ensure further economic development according to theoretical approaches in which educated labour is better at creating, implementing, and adopting new technologies, thereby generating growth. Innovative capacity is rooted in nation or region microeconomic environment and in the field such as the intensity of scientists and engineers in the workforce, but only $0.5 \%$ of labour in 2009 was employed in research in Latvia.
Taking into account that Latvia by European Innovation Scoreboard 2010 is among 'modest innovators' taking last place in EU-27 range and performance of Latvia is estimated as well below of other countries of EU, more attention has to be focus on eliminating relative weaknesses in the nearest future. One of the opportunities to eliminate the weaknesses is efficient use of available EU structural funds to ensure investments in education and science.

The statistical data have showed that labour is more used in final good sector not in research sector that produces technology, and the lowest added value to GDP per $1 \%$ of the labour was in agriculture and fishing caused by high proportion of labour allocated in this sector, but the highest proportion was in financial mediation and business activities.

Even if labour quality and technology could be identically to the average EU member states achieved, high proportion of industries that produce goods and services with relatively low added value in Latvia could also become an obstacle to meet the maximum income level and technological innovation. Simultaneously it could be an alert for economic restructuring through labour concentration in economic sectors.

This work has been supported by the European Social Fund within the project 'Support for Doctoral Studies at University of Latvia'.

\section{References}

Angeles L. (2010), Demographic transitions: analyzing the effects of mortality on fertility - Journal of Population Economics, Vol. 23 Issue 1, p. 99-120

Benhabib J., Spiegel M.M. (1994), The Role of Human Capital in Economic Development: Evidence from Aggregate Cross-Country Data.- Journal of Monetary Economics Vol. 34, pp. 143-173

Becker G.S., Barro R.J. (1988), A Reformulation of the Economic Theory of Fertility - Quarterly Journal of Economics, Vol.103, Issue 1, pp. 1-26.

Becker G.S, Murphy K.M. and Tamura, R. (1990), Human Capital, Fertility, and Economic Growth - Journal of Political Economy, Vol. 98 (5, part 2), pp. 12-37.

Central Statistical Bureau of Latvia. Home page on-line: http://www.csb.gov.lv/

Depopulation in Latvia (2010) - Riga, University of Latvia, Department of Statistics and Demography. University of Latvia Academic Publisher, $60 \mathrm{p}$.

Eglite P. (2009), Response to Family Policy in Latvia. In: Promotion of Social Policies - An Investment in the Future. Canada - Euripean Union - Baltic states - Nordic Countries. Riga, European Commission Representation in Latvia and University of Latvia, pp.114-125

Estonian Human Development Report 2007 (2008). Online: http://www.kogu.ee/public/trykised/EIA07_eng. pdf (Nyhan B. (2001), Human recource development in Europe - At the crossroads. In: Training in Europe. Second report on vocational training research in Europe 2000, Vol. II Luxembourg: Office for Official Publications of the European Communities, p.610) 
Europe in figures - Eurostat year book 2010 (2010). On-line: http://epp.eurostat.ec.europa.eu/cache/ITY_OFFPUB/ KS-CD-10-220/EN/KS-CD-10-220-EN.PDF

European Innovation Scoreboard 2010, The Innovation Union's performance scoreboard for Research and Innovation. On-line: http://www.proinno-europe.eu/sites/ default/files/docs_EIS2010/IUS_2010_final.pdf

Fougere M., Harvey S., Mercenier J., Mérette M. (2009), Population ageing, time allocation and human capital: A general equilibrium analysis for Canada - Economic Modelling, Vol.26, Issue 1, pp. 30-39

Galor O., Weil D.N (1996), The gender gap, fertility, and growth - American Economic Review, Vol. 86 Issue 3, pp. 374-387, 14 p.

Global Governance of Science (2009), Report of the Expert Group on Global Governance of Science to Science, Economy and Social Directorate, Directorate-General for Research, European Commission, Luxembourg: Office for Official Publications of The European Communities, p. 44

Hanushek E.A. (2004), Economic Analysis of School Quality. European Economy: Quality and Efficiency in Education - Special Report No 3 (Brussels: Directorate-

General for Economic and Financial Affairs, European Commission), pp. 29-48

Kersyte J., Krisciunas K. (2008), Bussiness's Vision on Competence of Researchers in Knowledge-based Economy - European Integration Studies, No.2, pp. 128 134

Komp K., van Tilburg T., van Groenou M.B. (2009), The influence of the welfare state on the number of young old persons -Ageing \& Society, Vol. 29 Issue 4, p. 609-624

Krumins J. (2009), The Social Impact of Demographic Changes. In: Promotion of Social Policies, An Investment in the Future. Canada - European Union - Baltic States - Nordic Countries, Riga: European Commission Representation in Latvia and University of Latvia, pp. 169-171.

Krumins J. (1993), Length of life - trends and problems of increase - Riga, University of Latvia, 192 p.

Kyriacou G. (1991), Level and growth effects of human capital: a cross-country study of the convergence hypothesis. New York, NY: C.V. Starr Center fron Applied Economics, New York University, 29 p.

Latvian National Developmnet Plan, 2007-2013, Ministry of Regional Development and Local Government of the Republic of Latvia. On-line: http://www.nap.lv/ in_site/tools/download.php?file=files/text/National development plan_2007-2013 lat.pdf
Latvian Strategic Development Plan, 2010 to 2013, 09.04.2010. Cabinet of Ministers Oder No.203. On-line: http://www.likumi.lv/doc.php?id=208079

Melihovs A., Davidsons G. (2006), Progress of production and human capital role of the Latvian economy growth - Bank of Latvia. On-line: http://www.bank.lv/ publikacijas/petijumi/petijumi/3840

Mezeniece M., Feifere S., Rivza B. (2010), Financing mechanism for research institutes in the field of agriculture in Latvia - Annual $16^{\text {th }}$ International Scientific Conference Proceedings Jelgava, Latvian University of Agriculture, pp. 35-41

Nelson R.R., Phelps E.S. (1966), Investment in humans, technology diffusion and economic growth.- American Economic Review 56, No.2 (May), pp. 69-75.

Patent Office of the Republic of Latvia. On-line: http://www. $\underline{\text { lrpv.lv/index.php?lang=EN\&id }=186}$

Romer P. M. (1990), Endogenous Technological ChangeThe Journal of Political Economy, Vol. 98, No. 5, Part 2: The Problem of Development: A Conference of the Institute for the Study of Free Enterprise Systems, pp. 71-102.

Silins A. (2004), New borders of science under globalization. In: Latvia in Europe. Visions of the future - Riga, Baltic Center for Strategic Studies, Latvian Academy of Sciences, pp. 87-103

Spence A.M. (1973), Job market signaling - Quarterly Journal of Economics, Vol.87, No.3, pp. 355-374

Teixera A.A.C., Fortuna N. (2010), Human capital, R\&D, trade, and long-run produktivity. Testing the tehnological absorption hypothesis for Portuguese economy, 19602001 - Research Policy, pp. 1-16

The World Bank, Knowledge Assesment Methology. Online: www.worldbank.org/kam

Zvidrins P. (2009), Depopulation in the Baltic States. In: XXVI International Conference. Abstracts. Paris. Online: http://iussp2009.princeton.edu/abstractViewer. aspx? submissionId $=91919$

Zvidrins P. (2004), Development of Latvia's population: presence and future. In: Latvia in Europe. Visions of the future - Riga, Baltic Center for Strategic Studies, Latvian Academy of Sciences, pp. 258-275

Regions 2020: An Assessment of Future challenges for EU Regions (2008), Commission of the European Communities. On-line: http://ec.europa.eu/regional policy/sources/docoffic/working/regions2020/index en.htm

The article has been reviewed.

Received in April, 2011; accepted in June, 2011. 